Civil SocietY AND THE LEgITIMATION OF GLOBAL

GOVERNANCE

Jan Aart Scholte

CSGR Working Paper No. 223/07

March 2007 


\title{
Civil Society and the Legitimation of Global Governance Jan Aart Scholte
}

CSGR Working Paper No. 223/07

March 2007

\author{
Abstract: \\ (From Introduction)
}

Along with the general intensified globalisation of social relations in contemporary history has come an unprecedented expansion of regulatory apparatuses that cover planetary jurisdictions and constituencies. On the whole, however, this global governance remains weak relative to pressing current needs for global public policy. Shortfalls in moral standing, legal foundations, material delivery, democratic credentials and charismatic leadership have together generated large legitimacy deficits in existing global regimes. This fragile overall legitimacy has in turn constituted a major obstacle to achieving the substantial further growth of global-scale regulation that is required to secure decent human lives for all in a more global world. Insufficient capacities for global governance and insufficient legitimacy of global governance are thus coupled in damaging mutual reinforcement.

This paper argues that - although there are of course considerable variations across different global governance institutions and different civil society initiatives - the general picture has been one of but partially realised potentials of legitimacy promotion. Like the tip of the proverbial iceberg, civil society activities concerning global regulation have so far made visible only a fraction of the total mass of possibilities. Hence prescriptions for the future centre on 'more' and 'better'. Regarding more quantity, urgently required greater positive legitimation of global governance can be promoted with more civil society engagement, covering more regulatory institutions and extending through more stages of the policy process. Regarding better quality, to have greater positive legitimation effects civil society relations with global governance generally need to be more inclusive, more competent, more coordinated, and more accountable. Both sides to the interchange - civil society associations on the one hand and global regulatory bodies on the other - can take a range of measures to further these ends.

\section{Keywords:}

Globalisation, civil society, legitimacy, global governance, public policy.

\section{Contact Details:}

Centre for the Study of Globalisation and Regionalisation (CSGR)

University of Warwick

CV4 7AL Coventry (UK)

\section{Scholte@warwick.ac.uk}




\section{CIVIL SOCIETY AND THE LEGITIMATION OF GLOBAL GOVERNANCE}

\section{Introduction}

Along with the general intensified globalisation of social relations in contemporary history has come an unprecedented expansion of regulatory apparatuses that cover planetary jurisdictions and constituencies. On the whole, however, this global governance remains weak relative to pressing current needs for global public policy. Shortfalls in moral standing, legal foundations, material delivery, democratic credentials and charismatic leadership have together generated large legitimacy deficits in existing global regimes. This fragile overall legitimacy has in turn constituted a major obstacle to achieving the substantial further growth of global-scale regulation that is required to secure decent human lives for all in a more global world. Insufficient capacities for global governance and insufficient legitimacy of global governance are thus coupled in damaging mutual reinforcement.

It is widely supposed - by activists, officials and academics alike - that civil society engagement of global regulatory institutions can do much to redress these shortcomings in legitimacy. On this view, civil society involvement could inject values and voice that bolster the moral and democratic legitimacy of global governance. In addition, it is posited, relations with civil society associations could through the provision of vital information, insights and methods enhance the technical performance of global governance agencies. Furthermore, civil society initiatives could promote the formalisation of those global governance activities that have operated with little or no legal frameworks. Civil society associations could moreover support charismatic leaders for global governance, albeit hopefully executive heads who follow a moral, democratic, competent and legal course. 
Yet does the record fulfil these hopes and expectations? How far have civil society activities in practice advanced the legitimation of global regulation to date? What do the experiences of several decades of intensified civil society engagement of global governance institutions suggest regarding ways to enhance these legitimation effects in the future?

This paper argues that - although there are of course considerable variations across different global governance institutions and different civil society initiatives - the general picture has been one of but partially realised potentials of legitimacy promotion. Like the tip of the proverbial iceberg, civil society activities concerning global regulation have so far made visible only a fraction of the total mass of possibilities. Hence prescriptions for the future centre on 'more' and 'better'. Regarding more quantity, urgently required greater positive legitimation of global governance can be promoted with more civil society engagement, covering more regulatory institutions and extending through more stages of the policy process. Regarding better quality, to have greater positive legitimation effects civil society relations with global governance generally need to be more inclusive, more competent, more coordinated, and more accountable. Both sides to the interchange - civil society associations on the one hand and global regulatory bodies on the other - can take a range of measures to further these ends.

To develop this argument the discussion below first summarily describes the contemporary growth of global-scale governance institutions and their still inadequate proportions and legitimacy. The second section reviews the expansion of civil society engagement of global regulatory arrangements and the positive contributions (actual as well as prospective) of these activities for the legitimation of those regimes. The third section elaborates on shortcomings in current civil society relations with global governance agencies that limit positive legitimation effects, and offers suggestions to improve matters. 
The thoughts presented here derive from a decade of investigations of civil society involvement in global governance. Much of this research has examined the issue-areas of finance and trade, including in particular civil society engagement of the International Monetary Fund (IMF), the United Nations (UN), the World Bank Group, and the World Trade Organisation (WTO) (O'Brien et al., 2000; Scholte and Schnabel, 2002; Scholte, 2002, 2004). In addition, fieldwork on civil society and global democracy conducted across five continents between 2001 and 2005 has encompassed a broader range of global issues and regulatory instruments (Scholte, 2003, forthcoming). Experiences with facilitating several civil society workshops on global governance and with drafting the IMF 'Guide for Staff Relations with Civil Society Organizations' (IMF, 2003) have also informed the analysis that follows.

The paper is deliberately sweeping in its coverage. Much more could be said, and has been said elsewhere, on a number of the issues that are addressed more summarily here: e.g. the character of global regulation; the existence or otherwise of global civil society; problems of civil society accountability in global politics; etc. The aim of the present analysis is not to be comprehensive on any of these matters, but rather to distil and synthesise key points on various dimensions of the problem at hand in order better to grasp the relationship between civil society and legitimacy in global governance.

To the author's knowledge other existing research and writing has not consolidated such an analysis. The issue of legitimation dynamics is often mentioned or implied in the growing literature on civil society engagement of global regulatory processes, but it has never been the focal concern. Likewise, in official circles the recent Report of the Panel of Eminent Persons on United Nations-Civil Society Relations raised the question in passing (Cardoso, 2004: 27-8), but did not elaborate a direct and systematic response to it. Hence it may be hoped that this paper helps to move the debate forward. 


\section{Global Governance and Its Legitimacy Gaps}

Contemporary society has become a more global society. The collective lives of human beings have over the past 50-60 years acquired notably larger planetary (that is, Earth-spanning) dimensions. This increase in transplanetary links between people has both material and ideational aspects. In terms of concrete flows, communications, travel, production, trade, money, finance, organisations, laws, conflicts, ecology and health now have global aspects to overall degrees not previously witnessed in human history (Held et al., 1999; Scholte, 2005). In addition to such tangible links, growing global connectivity is constituted mentally through greater consciousness, imagination, narrative, and perception of planetary social spheres (Robertson, 1992). One carefully calculated multivariate economic, political and social measure indicates that the level of globality across the world rose (on a scale 0-1) from 0.23 in 1982 to 0.68 in 2004 (CSGR, 2007).

Like all realms of social relations, global domains require governance, that is, the formulation and application of rules. Such rules may be formal or informal, strict or loose, permanent or transitory, public or private, enabling or oppressive. Whatever the character, though, regulation of some kind must develop if transplanetary connections among people are to have stability and longevity. Governance brings the degree of order and predictability needed for sustainability.

Not surprisingly given these functional imperatives, multiple regulatory arrangements for planetary affairs have grown in tandem with accelerated globalisation in contemporary history. Preexisting global governance institutions have seen large increases in their mandates and resources to handle expanding global relations, and new global regulatory agencies have proliferated. However, these institutional developments have still lagged far behind the needs of global public policy: e.g. on arms proliferation, climate change, intercultural polarisations, financial crises, infectious diseases, illicit trafficking, persistent poverty, technology divides, and so on. The construction of effective rules and 
regulatory processes for planetary-scale issues therefore remains a prime challenge for contemporary politics.

Of course, not all governance of global affairs has to occur through institutions with a planetary scope. For one thing, contrary to some premature obituaries, most nation-states have substantial capacities to regulate the ways that global flows impact on their territories and populations. Moreover, certain major states (the USA above all) have global reach and play regulatory roles far beyond their formal frontiers. In addition, considerable regional regulation of global production, trade and finance has developed over the past half-century: for example, with the emergence of the European Union (EU), the African Union (AU), the East Asian Community (EAC), etc. Concurrently, worldwide trends of localisation have brought substantial devolution of much governance, including part of the regulation of global matters such as transnational capital investment and various aspects of ecological degradation.

Hence the governance of global affairs is not taking shape as a global government, in the sense of a centralised nation-state scaled up to planetary proportions. Regulation of global commerce, global migration, global disease, and so on occurs in a diffuse fashion through multiple kinds of institutions spread across several scales of organisation, local to global. Theorists have variously referred to this condition as 'polylateralism', 'networked governance', 'polycentrism', 'empire', 'new medievalism', 'cosmocracy', 'mobius-web governance', 'complex sovereignty', and 'disaggregated world order' (Wiseman, 1999; Reinicke, 1999-2000; Scholte, 2000b; O'Brien et al., 2000; Hardt and Negri, 2000; Friedrichs, 2001; Keane, 2003; Rosenau, 2003; Grande and Pauly, 2004; Slaughter, 2004).

Thus to highlight the significance of global governance is not to posit or advocate the emergence of a planetary sovereign. On the contrary, there is much to be said on practical as well as democratic grounds for the principle of subsidiarity, 
whereby policy decision points on global matters lie as closely as possible to the affected people. Yet also when one maintains that multi-scalar arrangements underpinned by the subsidiarity principle are the way forward for regulation of global issues, there still remains an urgent need today for greatly expanded planetary-scale governance. Even if global governance is restricted to that which cannot be undertaken regionally, nationally and locally, major aspects of the regulation of global communications, travel, production, trade, money, finance, conflicts, ecology and health cannot be devolved. The current requirement is therefore for more global governance, not less.

Conventional political thought has usually equated 'global governance' with 'intergovernmental organisations'. However, other kinds of global regulatory apparatuses have also appeared over recent decades, in part because the growth of traditional multilateral institutions has not keep pace with the needs of rapid globalisation. As a result one might today distinguish half a dozen types of global governance arrangements. The most familiar form of planet-spanning regulatory body is indeed the formal intergovernmental agency, the old-style 'international organisation'. This category includes well-known entities like United Nations (UN) institutions, as well as less publicised bodies like la Francophonie and the Organisation of the Islamic Conference (OIC). In addition, recent decades have witnessed major growth of planetary-scale regulation through transgovernmental networks and accompanying global administrative law (Raustiala, 2002; Slaughter, 2004; Kingsbury and Krisch, 2006). In these cases senior officials from multiple states jointly pursue governance of common concerns with informal collaboration through memoranda of understanding, conferences, and day-to-day communication. Examples include the Competition Policy Network, the Group of Eight (G8), and the Nuclear Suppliers Group. Less extensive to date, but potentially more important for the future, is global governance through interregional arrangements (Gilson, 2002; Hänggi et al., 2005). In these cases, regulation of global issues is pursued among several macro-regional bodies, for example, between the EU and MERCOSUR (the 
Southern Common Market) or ASEAN+3 (the Association of South East Asian Nations plus China, Japan and South Korea). Still further global regulatory networks have a translocal character, linking provincial and municipal governments across the planet in initiatives like United Cities and Local Governments (UCLG) and ICLEI-Local Governments for Sustainability. Meanwhile, other expansion of global governance has transpired in recent decades through private regulatory mechanisms run by business consortia and/or civil society associations (Cutler et al., 1999; Ronit and Schneider, 2000; Hall and Biersteker, 2003). Examples of private global governance include the Forestry Stewardship Council (FSC, to promote ecologically sustainable logging), the Global Reporting Initiative (GRI, to advance corporate social responsibility), and the International Accounting Standards Board (IASB, to elaborate and harmonise modes of financial reporting). A final category of growing global governance in contemporary history involves hybrid arrangements that combine public and private elements (Bull and McNeill, 2007). Examples include the Internet Corporation for Assigned Names and Numbers (ICANN, started in 1998), the Global Compact (launched in 2000) and the Global Fund to Fight AIDS, Tuberculosis and Malaria (established in 2002).

Appreciated in this multifaceted way, considerably more global governance has developed over recent decades than is suggested by looking at intergovernmental multilateralism alone. Accounts of global governance particularly tend to underestimate, or overlook altogether, the substantial contemporary significance of transgovernmental networks and private global regulation. In addition, interregionalism, translocalism and public-private hybrids are important in certain areas and may become major forms of global regulation in the years to come.

Yet for all of this institutional innovation and expansion, global governance today still falls far short of needs. Much more and much better transplanetary regulation is needed to ensure that globalisation impacts positively on core attributes of a 
good society such as cultural vibrancy, democracy, distributive justice, ecological integrity, material well-being and peace.

Nor can major breakthroughs to larger and more effective global governance be expected in the absence of greater legitimacy for planetary regulation. Such global governance apparatuses as have developed so far generally lack firmly rooted support from those whom they govern (Zürn, 2005; Buchanan and Keohane, 2006). Indeed, frequently the persons subject to a given global regulatory arrangement are not even aware that it exists. Where the affected publics are cognizant of a global governance apparatus, they generally do not actively endorse it and often feel at best only a limited obligation to acknowledge its authority.

A governance framework can derive legitimacy from several sources, especially the five qualities of morality, legality, technical competence, democracy and charismatic leadership. With respect to morality, fair trade schemes with their explicit orientation to distributive justice generally enjoy greater legitimacy with global publics than the WTO. With respect to legality, grounding in international law tends to give the UN greater legitimacy than the informal G8. With respect to technical performance, the achievements of the United Nations Children's Fund (UNICEF) in promoting education and health of young persons bring that agency substantial public endorsement, whereas the legitimacy of the IMF has suffered from various failings of the macroeconomic adjustment policies that it has promoted. With respect to democracy, comprehensive direct stakeholder participation and accountability arguably secures the FSC more legitimacy than the United Nations Environment Programme (UNEP). With respect to charisma, James Wolfensohn by his person arguably bolstered public support for the World Bank at a time of considerable challenge, while the success of the World Wide Web Consortium (W3C) in global regulation of the internet owes largely to the inspiration of Tim Berners-Lee. 
The dynamics of legitimation are of course more complex than an artificially neat analytical distinction of five sources may suggest. In practice the different aspects of legitimacy are often overlapping and mutually reinforcing, so that it is difficult to specify how much of each strand is in play. For instance, much promotion of global human rights (enhancing moral standing) has occurred in tandem with giving voice to subordinated groups like indigenous peoples and women (enhancing democratic standing). On other occasions several sources of legitimacy can also be in tension. For example, much transgovernmental regulation is marked by (legitimating) strong technical efficacy and (delegitimating) weak legality. Other times prevailing global law may violate the moral sensibilities of substantial populations, say, on religious grounds.

These complexities duly noted, however, there can be little dispute that the overall current balance sheet for the legitimacy of global governance stands deeply in the red. Moral foundations, legal grounding, material delivery, democratic practice and charismatic leadership are sooner weak than strong in transplanetary regulation today. Again, this problem is critical: without greater legitimacy, global governance will not obtain the greater resources and powers that are needed to make the required major regulatory advances.

\section{The Legitimating Potentials of Global Civil Society}

Arguably civil society involvement in global governance can do much to address these legitimacy deficits. The following pages clarify how 'civil society' is understood in the present context and identify broad ways that globally oriented civil society activities can have legitimating effects on global governance. Before proceeding further, however, four qualifications are suitably inserted at this juncture.

First, the emphasis in the current discussion on civil society promotion of legitimate global governance does not deny the important contributions that can come from other quarters as well. For example, national and local governments, 
parliaments and political parties, the mass media, and business circles can also help to give firmer moral, legal, technical, democratic and/or charismatic qualities to global governance. The argument advanced here is not that civil society is the sole or even primary provider of legitimacy for global governance, but rather that civil society is a significant force whose potential fruits have thus far been inadequately nurtured. The roles of other players in legitimising global governance can be assessed in other writings (e.g. Scholte, 2006).

Second, the present argument does not presume that civil society activities in respect of global governance are inherently legitimating. On the contrary, interventions from civil society can often delegitimate global authorities by exposing immorality, illegality, incompetence and authoritarianism and in their quarters. The role of civil society is therefore one of vigilant monitoring rather than uncritical endorsement of global governance. One might hope that this accountability function of civil society would encourage global regulators to correct mistakes and bolster their legitimacy. However, the effect may also be to increase public awareness of malfeasance in global governance and thereby often justifiably - to weaken its legitimacy.

Third, civil society associations themselves are not intrinsically legitimate. These citizen groups, too, can suffer from unethical conduct, illegality, ignorance, undemocratic behaviour and ossified leadership (Ahrne, 1998). Indeed, a number of the suggestions for future improvements that are developed towards the end of this paper focus on upgrading the performance of civil society activities. Hence the approach taken here is not one of uncritical enthusiasm for civil society, but a measured assessment of opportunities that this citizen action offers to enhance legitimate global governance.

A fourth key qualification is that the present argument does not advocate legitimacy in global governance at all costs. In principle legitimacy can bring positive results, as it generally permits regulation to occur more energetically, 
efficiently and nonviolently. Yet it would hardly be desirable to have global governance that enjoyed overall public support but presided over, say, genocide or ecological ruin. Nor is the goal to achieve hegemonic legitimacy in a Gramscian sense, where the subjects of global governance are persuaded that the rules operate in their interest when the regime in fact oppresses them. However, legitimacy accorded to global governance by critically aware and actively mobilised citizens can help these regulatory apparatuses to thrive and produce positive results.

What then, more specifically, is meant by (global) civil society in the present context? This circumscribed paper is not the place to assess the multiple contending conceptions of civil society (Cohen and Arato, 1992; Kaldor, 2003; Edwards, 2004), or to elaborate an intellectual and political justification for the particular definition adopted here (Scholte, forthcoming). It can simply be affirmed that civil society is understood in this analysis to be a political arena where associations of citizens seek, from outside political parties, to shape the rules that govern one or the other aspect of social life. Civil society activities are an enactment of citizenship, that is, practices through which people claim rights and fulfil responsibilities as members of a given polity. These initiatives are also collective, involving citizens assembled in groups that share concerns about, and mobilise around, a particular problem of public affairs. As self-consciously political actions, civil society operations are steeped in struggles to affect the ways that power in society is acquired, distributed and exercised. However, civil society efforts to shape governance do not - in the way of political parties - aim to attain or retain public office.

Modern political theory has normally described and explained civil society in relation to the state. Under a statist conception the rules that civil society initiatives seek to shape are those that emanate from national (and within it local) government. Likewise, in this conventional perspective the citizenship that civil society activities enact is centred on and defined by the state. The civil society 
associations that engage the state are based in its territory and regulated under its laws. From the perspective of statist political theory, the notion of 'global civil society' appears to be an oxymoron.

Yet the key point is not that civil society relates to the state, but that it relates to a governance apparatus. When, as in the past, governance operated in a statist mode, with a near-complete focus on sovereign national territorial governments, civil society likewise concentrated on the state. However, as indicated earlier, regulation today involves many more institutional sites in addition to the nationstate, including a host of arrangements with a global scope. Not surprisingly, civil society associations have in line with this shift in the overall mode of governance also shifted their points of engagement. Thus, observing that many societal rules now emanate to a significant degree from global governance agencies of the various types described earlier, citizen action groups have in recent decades reoriented their activities partly towards those transplanetary regimes. This engagement of global governance institutions - together with attention to global issues, adoption of global organisational frameworks, use of global infrastructures, resources from global finance, and support from global solidarities among people - makes talk of 'global civil society' quite meaningful (Scholte, 2000a).

Indeed, civil society activities are pervasive in contemporary global governance (Florini, 2000; Edwards and Gaventa, 2001; GCS, 2001-; Clark, 2003; Batliwala and Brown, 2006). Parallel NGO Forums alongside UN-sponsored global issue conferences are one highly visible manifestation of this engagement. In addition, civil society is also involved in transgovernmental processes like the G8 and interregional processes like the Asia-Europe Meetings (ASEM). In some cases of private global governance like the FSC and fair trade schemes it is civil society associations themselves that formulate and administer the rules. Among the public-private hybrids civil society associations have actively campaigned in respect of ICANN and sat on the board of the Global Fund. 
The civil society associations that engage global governance institutions take many forms. Some are nongovernmental organisations (NGOs), that is, issuebased nonprofit agencies with a formal organisation, legal personality and professional staff. Many (albeit far from all) citizen initiatives on consumer problems, democracy promotion, development cooperation, environmental degradation, health, human rights, humanitarian relief, market regulation, the status of women, and youth questions are largely pursued through NGOs. Other civil society activities vis-à-vis global governance occur through social movements involving large, often informally organised, and sometimes even underground mobilisations of non-professional activists. Examples include many citizen actions on animal rights, caste discrimination, indigenous peoples, land tenure, peace, racial solidarity, religious belief, and working conditions. Thus the civil society that is relevant to global governance extends far wider than the transnational NGOs who cluster around Geneva, New York and Washington.

Civil society initiatives in respect of global governance also vary widely in other respects. In terms of size, for example, tens of thousands may gather around a G8 summit, while other actions involved handfuls of people. In terms of duration, the Anti-Slavery Society has several centuries behind it, while other NGOs are 'come-and-gos'. In terms of geographical scope, the campaign to ban land mines spanned all inhabited continents, while civil society actions on the use of debt relief monies can be highly localised. In terms of cultural context, many global civil society activities are steeped in western modernity, while others involve the assertion of indigenous life-worlds or religious revivalism. In terms of resource levels, Amnesty International and Greenpeace can draw on large funds and the most sophisticated technology, while the peasants of Vía Campesina often lack even their own land. In terms of constituencies, civil society interventions in global governance may advocate for anyone from multinational companies to the mentally ill. In terms of broad strategies, global civil society houses everything from the neoliberalism of the Cato Institute to the Trotskyism of the Fourth 
International. In terms of tactics, some parts of civil society will don establishment attire for face-to-face meetings in the offices of global governance agencies, while other citizen activists steadfastly refuse any direct contact with global authorities.

All of this diverse civil society activity can in principle significantly advance the legitimation of global governance on the several grounds discussed earlier. For example, with regard to legitimation on the basis of moral stature, many civil society associations have donned the mantle of 'conscience of the world' in respect of global governance institutions (Willetts, 1996). In this vein citizen group initiatives have prodded the transplanetary regulatory agencies to promote righteous ends like decolonisation, human rights, poverty eradication, fair trade, anti-corruption, peace, and ecological sustainability. Pressures from civil society have figured centrally in the development of countless global governance policies with a pronounced moral dimension, including sanctions against the former apartheid regime in South Africa, measures to advance gender equality, the Millennium Development Goals, the rescheduling and eventual cancellation of many poor-country debts, the Kimberley Process against so-called 'blood diamonds', initiatives to protect biological diversity, and so on. Conversely, civil society interventions have at other times undermined the legitimacy of global governance by highlighting purported moral flaws, for instance, with charges that policies of the WTO deepened social injustice. True, as noted earlier, civil society also houses 'uncivil' groups of fundamentalists, militarists, racists and ultranationalists; so its interventions in global governance do not always and inherently carry positive moral effect. However, one does not have to romanticise civil society to observe that these activities have on various occasions played a pivotal role in persuading global regulatory authorities to champion good causes. Public perceptions of the moral credibility of various forms of transplanetary regulation have then risen in consequence. 
Civil society energies have also in different contexts helped to generate legitimation (and delegitimation) of global governance in relation to legality. Advocacy by citizen groups has figured centrally in the formulation and ratification of countless treaties and resolutions with global legal force. Already in the 1940s, civil society inputs were instrumental in promoting the San Francisco Charter that set up the UN. Half a century later, civil society figured prominently (especially through the World Economic Forum) in launching the Uruguay Round that delivered the WTO in 1995. Likewise, the entry into force of the Convention to Prohibit Anti-Personnel Mines in 1999 and the creation of the International Criminal Court in 2002 resulted in good part from civil society campaigns. Conversely, civil society associations have questioned the legitimacy of some global governance by highlighting weak legal groundings, for example, in relation to transgovernmental processes like the $\mathrm{G} 8$ and certain private global governance mechanisms like instruments for corporate social responsibility (CSR). Similarly, several million street demonstrators in February 2003 undermined the legitimacy of a forthcoming invasion of Iraq that lacked full and specific legal sanction under the United Nations.

From a third angle, civil society associations have often contributed to the legitimation of transplanetary regulation by abetting the successful delivery of material objectives. Competent inputs from civil society can enhance policy development and operational work in global governance. Civil society groups can inject valuable information, insights, methods and advice into policy processes. Sometimes these data and perspectives replicate, confirm, reinforce and strengthen existing policy knowledge. On other occasions civil society interventions prompt adjustments to policy, for example, by bringing the latest news fresh from the field or by providing alternative views from quarters that official circles do not readily access. Challenges from civil society quarters to established policy can provoke a global governance agency to sharpen its thinking and improve its instruments. Engagement with civil society can also provide global regulatory institutions with an important gauge of the political 
viability or otherwise of a given project or programme. In certain situations civil society actors moreover themselves perform global regulation. For example, they may hold formal positions in transplanetary governance mechanisms, e.g., as members of the Board of the Global Fund, as parties to the FSC, and as supervisors of fair trade schemes. In addition, some global governance bodies subcontract parts of their operations to civil society agencies, particularly in situations where the citizen groups can perform the services in question more effectively than official bureaucracies. Needless to say, where civil society inputs undermine material delivery - e.g. with faulty information or flawed performance - they sooner contribute to a delegitimation of global governance.

Still another way that civil society activities can raise the legitimacy (or conversely emphasise the illegitimacy) of transplanetary regimes relates to democracy. From this fourth angle global governance can be legitimate when along with, or in some cases instead of, morality, legality, material delivery and charismatic leadership - it rests on participation by and accountability to the affected public(s). Civil society can promote 'rule by the people' in global governance in at least seven complementary ways (Scholte, 2003, forthcoming). For one thing, civil society associations can contribute significantly to public education about global governance, thereby empowering citizens to involve themselves meaningfully in these regulatory processes. Second, civil society interventions can stimulate public debate about current and possible future courses of global governance, thereby fuelling the active critical deliberations that lie at the heart of a vibrant democracy. Third, civil society groups can connect citizens directly to global governance authorities, through consultation exercises and the like. Fourth, civil society pressures can induce global governance authorities to be more open, visible and transparent about their operations, so that citizens are able to intervene more effectively in policy processes. Fifth, civil society organisations can serve a watchdog role that extracts greater public accountability from global regulatory agencies for their actions and omissions. Sixth, civil society actions can counter the various arbitrary social hierarchies 
(inter alia on lines of age, class, culture, gender, geography and race) that prevent citizens from having adequate and equal opportunities to shape global governance. Seventh, civil society initiatives can provide recognition and voice for political identities (for example, of indigenous peoples, religious revivalists and sexual minorities) that tend generally to be undemocratically marginalised and silenced in global politics. Of course, civil society can and does also fail to realise these democratising possibilities vis-à-vis global governance. In some cases civil society groups even exacerbate failings of global democracy through shortfalls of participatory and accountable practices in their own quarters. So civil society's democratic impacts on global governance are potential rather than automatic, but many positive effects of this kind have been had, and many more could be obtained.

Finally, civil society activities can promote legitimacy in global governance by promoting charismatic leadership of these regulatory institutions. As noted earlier, transplanetary regulation has, in contrast to contemporary national government, not usually sought or secured much legitimacy on the basis of the popular appeal of its executives. The norm at the head of these organisations has sooner been relatively faceless technocrats, and civil society groups have for the most part not challenged this tendency. That said, civil society associations themselves have inserted into global politics some charismatic personalities who have helped to draw media and popular attention to pressing issues of transplanetary regulation. Examples include José Bové, the Dalai Lama, Wangari Maathai, and Comandante Marcos.

Across all five main dimensions, then, civil society can do much to bolster - or where warranted to undermine - the legitimacy of global governance. True, civil society activities are not the only source of such legitimation; nor are civil society groups always sufficiently legitimate in their own right. Nevertheless, civil society houses some of the most powerful forces available today for the badly needed 
greater legitimation of global governance. Hence the final part of this discussion turns to steps that could bring a fuller realisation of the possibilities.

Global regulatory agencies have broadly (if sometimes rather belatedly and reluctantly) recognised the legitimising potentials of relations with civil society. As a result, most have over recent decades pursued notable initiatives to engage these citizen associations. In several cases civil society groups have actually held seats on global policymaking bodies like ICANN committees and the UN Commission on Sustainable Development. Since the mid-1990s many governments have added civil society practitioners onto their official delegations to global governance congresses. Sometimes (as in the 1990 Jomtien Conference on Education for All and the 2002 Monterrey Conference on Financing for Development) civil society attendees have taken the floor in their own capacity alongside state officials. Almost all global governance agencies have institutionalised some kind of mechanisms for civil society consultation. Even the UN Security Council has since the late 1990s permitted occasional informal briefings by civil society organisations under the so-called 'Arria formula'. A number of global regulatory agencies have appointed specially designated civil society liaison officers. Several including the IMF, the United Nations Development Programme (UNDP) and the World Bank have also prepared written staff guides for relations with civil society actors. A few multilaterals have furthermore introduced staff training courses on the subject. Most of these steps to 'open up' to civil society were barely conceivable thirty years ago.

Global governance agencies have often presented such measures as 'concessions' to civil society pressures, but the benefits and dependencies are usually mutual. Thus the UN needs its civil society 'partners' (to lend it moral authority, technical support, and greater trappings of democracy) as much as vice versa. Global economic institutions need to have at least some influential civil society associations inside the tent at least some of the time, rather than 
always and only to face civil society opposition outside. In contrast to transplanetary governance arrangements created before the 1990s, recent additions like the Global Compact and the Global Fund have tended to build in a significant civil society component from the outset. The 1994 Marrakech Agreement that founded the WTO also explicitly provides for relations with civil society.

Critics may enquire sceptically what kind of legitimation results from such civil society engagement with global governance. Do these relationships veritably enhance the moral, legal, technical, democratic and/or charismatic qualities of transplanetary regulation? Or do the overtures from official quarters to civil society amount to a hegemonic disciplining and cooptation of dissent, whereby a surface legitimation disguises and suppresses a deeper illegitimacy?

Answers to these questions can go either way, depending partly on concrete evidence relating to specific contexts and partly on the theoretical and political predispositions of the questioner. Certainly substantial cases can be developed either for optimistic liberal and Polanyian readings of the situation (e.g. Keck and Sikkink, 1998; Munck, 2006) or for critical Gramscian and poststructuralist assessments (e.g. Gill, 2003; Hardt and Negri, 2004). However, commentators of all persuasions would affirm (albeit in different ways) a need for better civil society legitimation of global rules.

\section{Towards the Future}

What could be done to improve the legitimation dynamics of civil society relations with global governance institutions? What steps are advisable both to increase the interchanges and to generate a positive rather than a hegemonic legitimation of global regulation? In a word, what is wanted in the period ahead is more, more inclusive, more competent, more coordinated, and more accountable civil society engagement at the heart of policy processes of the full range of global 
governance processes. The remainder of this paper elaborates on these broad needs in turn.

\section{More relations}

In the first place, then, greater and better legitimation of global governance can be obtained through sheer increases in civil society engagement of the regimes in question. Important though the relations to date have been, the scale could be substantially larger. On the one hand, more civil society associations could direct more of their work towards questions of global governance. At present the circle of serious engagers remains relatively small. On the other hand, more transplanetary regulatory agencies could nurture more exchanges with civil society groups. Important though a number of global governance initiatives in this area have been, the overall scale thus far remains relatively modest.

It is also important that civil society efforts on global governance better cover the full range of relevant institutions. Current civil society attentions are disproportionately concentrated on the older generation of intergovernmental agencies and remain comparatively neglectful of newer arrangements like transgovernmental networks and private governance instruments that generally suffer greater legitimacy deficits. Anne-Marie Slaughter has argued that civil society engagement offers one of the best ways to enhance justice in respect of transgovernmental regulation (2004: 220-1, 240). Yet to date few citizen associations have taken up this challenge, apart from sporadic attention to the G8. Likewise, key private global governance arrangements in areas like communications and finance have so far usually stayed off the civil society campaign map, again limiting important prospective (de)legitimation effects.

Indeed, civil society associations should arguably construct future advocacy more in terms of issues than in regard to specific institutions. As seen earlier, a global problem tends to be regulated through a diffuse, trans-scalar, multi-actor 
complex, rather than in a centralised fashion through a single agency. Thus, for example, civil society initiatives would better engage the polycentric network that governs global trade rather than direct efforts at the WTO alone. Likewise, it is a multifaceted regulatory apparatus that matters for global ecological affairs rather than CSR, the FSC or UNEP per se. The notable impacts of civil society campaigns on debt relief and women's rights have resulted partly from a strategy of engaging the overall relevant governance framework instead of just one or the other institutional node.

Yet wherever in global governance civil society associations engage, greater positive legitimation effects could result if these citizen inputs were integrated more into the whole policy processes, starting from initial agenda setting and continuing all the way through to retrospective evaluation. In many cases global regulatory agencies have mainly limited civil society involvement to later stages of policy formulation, after the principal decisions have been taken. Official circles then expect 'consultation' of civil society to give a veneer of public endorsement to policy that has in effect already been decided. Even when civil society inputs are incorporated earlier - as in the preparation of Poverty Reduction Strategy Papers (PRSPs) for low-income countries - governance authorities often do not adopt the kind of open, respectful, listening, learning attitudes to citizen groups that would allow maximum policy enhancement to be taken from these exchanges.

True, global governance staffs have several understandable grounds for caution about possible delegitimating effects of bringing civil society actors too far into policy processes. For example, official circles may require degrees of confidentiality when (as in cases such as interest rate adjustments and troop deployments) disclosure to civil society circles could compromise policy effectiveness. Likewise, global regulatory bodies might need to tread carefully when exchanges with civil society actors could disrupt their relations with legitimate governments. In addition, transplanetary governance agencies might 
want to curtail contacts with civil society associations when the global institutions could thereby become unhelpfully embroiled in the political struggles of others (election campaigns, ethnic conflicts, etc.). Furthermore, official circles may worry about becoming unwittingly involved with 'uncivil' society, particularly in situations where they can get only limited information about the groups.

Yet global authorities sometimes also overplay such cautions as a way to evade the challenges of deeper dialogue with civil society. Similarly, complaints of a lack of time for civil society outreach are often heard somewhat too quickly and insistently from officials who prefer to avoid this added complication to their work. Most global governance agencies could substantially expand relations with citizen groups without encountering major problems of confidentiality, unconstructive political exposure and overworked staff.

\section{More inclusive relations}

At the same time as increasing the quantity of relations between civil society and global governance, an enhancement of this legitimation dynamic also requires substantial improvements in the quality of these interchanges. A key step in this regard is to develop more inclusive interchanges that encompass the whole of society, including in particular marginalised and subordinated people.

To date the 'civil society' that engages global regulatory institutions has on the whole disproportionately involved limited and structurally privileged sectors of humanity. Past exchanges have especially favoured a global elite of culturally western, university-educated, English-speaking professionals. In the process many other citizen voices have been sidelined. As a result, patterns of civil society relations with global governance have generally reproduced the arbitrary inequalities of society at large. Civil society access to global governance has been predominantly Northern, urban, wealthy, male-led, and white - and moreover has often excluded non-western cultures, disabled persons, youth, 
lower castes and sexual minorities. To this extent there are substantial grounds to speak of hegemonic legitimation processes in which diversity and dissent are suppressed (however subtly and in many cases also unintentionally).

To counter these exclusionary tendencies both sides - civil society actors as well as global regulatory institutions - need to make far more proactive efforts at wider involvement than witnessed so far. A laissez-faire approach to civil society engagement of global governance invariably leads, as in any 'free market', to an overwhelming dominance of the strong. A positive development of the past decade has seen the growth of a rhetoric of inclusion in global politics, particularly in respect of 'the South', 'the grassroots', and 'gender mainstreaming'. However, in practice the prevailing pattern remains for better resourced and more forceful North-based professional advocates (more often than not men) to speak in global governance quarters instead of (and sometimes purportedly for) South-based and otherwise marginalised constituencies. Much more sustained deliberate actions are needed to advance equality of opportunity to enter civil society relations with global governance. In order to attain more tenable legitimacy, global regulatory bodies need more vigorously to embrace diversity and connect through civil society with the whole of an incipient global polity: peripheries as well as metropoles; small enterprises as well as big capital; peasants as well as agribusiness; informal workers as well as mainstream labour unions; religious revivalists as well as secularists; indigenous cultures as well as modernists; young persons as well as older adults; people of colour as well as whites; the disabled as well as the able-bodied; lgbt circles as well as heterosexuals; lower as well as upper castes.

In particular this more inclusive orientation requires a conception that does not as most global governance agencies currently tend to do - equate civil society with NGOs. Global regulatory authorities generally find it more comfortable and convenient to identify civil society activities in ways that they readily understand and more easily engage. NGOs present a relatively known quantity, in the sense 
of being modern, formal, legal, bureaucratic, compact, professional organisations - usually also with English-speaking staff. In these broad structural terms NGOs are quite similar to global regulatory bodies. For all that the two sets of actors may have heated disagreements over some policy questions, they tend to embody similar kinds of social exclusions. Indeed, many subordinated circles (including, for example, some faith groups, indigenous peoples, landless peasants, disaffected youth, and slum dwellers) find the NGO form to be culturally alien and - for their purposes - politically ineffective. These constituencies frequently prefer social movement modes of action: more informal, diffuse, fluid, populous, horizontal and spontaneous (Eschle and Maiguascha, 2005; Della Porta, 2006). Thus to achieve greater inclusion - and thereby deeper legitimacy - global governance institutions must give far more attention to devising means to relate to non-NGO expressions of civil society.

Meanwhile NGOs themselves could in general also pursue greater efforts to develop better understandings of and communications with social movements on global governance issues. Some NGOs have nurtured substantial links of this kind, including organisations like the Brazilian Institute of Social and Economic Analysis (IBASE), Focus on the Global South, and NGOs supporting the Movement for the Survival of the Ogoni People (MOSOP). Since 2001 the World Social Forum has also provided a constructive meeting ground for NGOs and social movements. However, most NGO interlocutors with global regulatory agencies rarely trade elite corridors for squatter camps. In Geneva and Washington the civil society world is sooner CNN than Franz Fanon.

One way to counter this NGO inbreeding with official power is to encourage more rotation of the civil society actors who enter dialogue with global governance agencies. True, as is elaborated under the next heading, an enhanced legitimation dynamic also wants the greater competence that is born of experience, which implies a certain continuity of personalities. However, as in any other vocation, too much continuity of personnel in civil society relations with 
global governance can lessen capacities to deliver new information, critical analysis, alternative worldviews, and out-of-the-box advice. Civil society careerists ensconced in Brussels and New York can sometimes jealously guard their privileged access to global policy processes. In the worst cases a tired civil society establishment may counterproductively obstruct the entry of energetic newcomers who could reinvigorate moral sensibilities, convey the latest technical advances, and inject wider democratic voice. Civil society offers veritable legitimation at the global governance table not by cooptatively warming up the seats, but by counter-hegemonically heating up the proceedings.

\section{More competent relations}

Along with wider inclusion, relations between civil society associations and global governance institutions need to be marked by ample mutual comprehension if the interchanges are fully to realise their potentials to advance legitimation. Both sides include parties who have impressive information and insight about the other, but overall the current picture is often marked by considerable ignorance. Thus a major requirement for greater legitimation of global governance through relations with civil society is improved competence on the part of activists and officials alike to deal with one another.

Global governance institutions could implement various measures to this end. For one thing, all global regulatory bodies could follow the example of UNDP and the World Bank in appointing experienced specialists to run their civil society bureaux. A number of other agencies have allocated these tasks to generalists who have no particular expertise regarding citizen action groups. Likewise, global governance institutions could suitably emphasise disposition towards and experience in outreach to civil society when they select positions (like heads of country offices) where these contacts are especially important. 
Meanwhile, for the benefit of global governance staff in general, written guidelines for civil society liaison could be prepared for those regulatory agencies that so far lack such an explicit framework. Moreover, all such texts could be given operational effect, as opposed to being merely optional reference material. Building on these documents, global regulatory bodies could offer their staff systematic training on relations with civil society organisations. Few of these agencies at present provide such support, instead leaving the conduct of civil society liaison largely to the staff's intuitions. Backed by operational guidelines and training, staff performance reviews could then reasonably include effective civil society liaison as one of the assessment criteria, thereby introducing a direct link between achievements in this area and personal career progress.

Other administrative routines, too, could be altered to enhance global governance outreach to civil society. For example, institutions can amend the pro forma for policy documentation (e.g. programme strategy papers, back-to-office reports, retrospective evaluations) to include a specific heading on relations with civil society. Officials could thereby be encouraged to do more to fill in the relevant boxes. In addition, global governance institutions would generally benefit from keeping more systematic and up-to-date records of contacts in civil society. Often departing officials leave their successors very few and poorly kept files on this subject, thereby compelling each newcomer to develop links with civil society largely from scratch.

On the side of civil society, improved competence on engagement of global governance often requires that campaigners stay the course on specific issues and institutions. Some civil society organisations have through long-term sustained efforts developed a deep engagement regarding certain agencies and areas of global regulation. Illustrative examples include the Southern and Eastern African Trade Information and Negotiations Institute (SEATINI) and the Japan Center for International Finance (JCIF). However, many civil society initiatives fail to acquire sufficient depth on any policy area, following the caprice of headlines 
and sponsors to flit from one global governance problem to the next. In this way civil society herds have moved from debt to trade, from trade to war, from war to CSR, and so on.

Much as global governance officials require training in respect of civil society, citizen activists for their part also generally need more capacity enhancement in respect of transplanetary regulation. Even advocates with university degrees often lack sufficient information and analytical tools to map global governance processes and the power dynamics that shape global policies. The current emergence of university courses on global public policy can help to deepen future civil society competence, particularly in NGOs. In addition, however, greater activist education through 'popular universities' of the kind found in Brazil and Scandinavia is needed to raise capacities in social movements that campaign on global governance issues.

Along with upgraded conceptual insight, civil society campaigners on global governance issues often also need a sharper strategic orientation. Even many veteran activists have not systematically and explicitly thought through the underlying values and overarching visions that motivate their engagement. The World Social Forum initiative has been helpful in highlighting issues of overall strategy, and several texts on globalisation and its governance (e.g. Klein, 2000; Bello, 2002; Stiglitz, 2002) have served a manifesto-like purpose for some civil society practitioners. However, most citizen activists have not carefully and precisely identified what they find lacking in currently prevailing policy paradigms, let alone how more specifically they would reconstruct those strategic frameworks. In short, civil society efforts to promote more legitimate global governance are hampered to the extent that the advocates lack a clear conception of what, beyond the issue immediately at hand, they are advocating.

Increased civil society competence can also be pursued in respect of campaign tactics. True, the effectiveness of citizen group initiatives on global governance is 
often highly constrained by limited resources. The best devised action plans are naught without sufficient people, equipment and money to execute them. Thus more - and more reliable - resourcing of civil society engagement of transplanetary governance is an obvious priority for the future. A chronic lack of means has led too many able campaigners to abandon their efforts in despair.

That said, improved tactics can also make limited resources go further. One key step in this direction is discussed at greater length below: namely, better coordination of civil society initiatives regarding global regulation. In addition, civil society groups working on global governance could generally do more to exploit the possibilities of mobilising constituents through the Internet and other mass media. More cleverly still, citizen advocates can pursue emancipatory causes in ways that harness hegemonic forces and their superior resources. For example, the civil society campaign for access to essential medicines has prompted global capitalists to question and qualify the existing regime of intellectual property rights. Similarly, poorly resourced movements of Dalit women, indigenous peoples and other subordinated groups have been able to turn the hegemonic global human rights regime to their advantage.

As these examples show, civil society associations can draw on rich past experiences to further their campaigns for more legitimate global governance. What is generally lacking, however, are effective mechanisms for sharing of, and mutual learning from, this accumulated competence. True, various research projects have documented the successes and failures of a number of civil society initiatives on matters of global regulation. Arguably civil society associations could make much more and better use of publications like the Global Civil Society Yearbook (GCS, 2001-), studies on civil society engagement of global governance agencies commissioned by the Montreal International Forum (FIM, 2007), reports prepared through the North-South Institute (NSI, 2007), and a number of edited collections and monographs (Willetts, 1996; Fox and Brown, 1998; Florini, 2000; Edwards and Gaventa, 2001; Scholte and Schnabel, 2002; 
Clark, 2003; Martens, 2005). Likewise, the fruitful collaborations nurtured over the past decade between campaigners and researchers on global governance would helpfully be much expanded and deepened (Brown et al., 2001).

Alongside academic research, more could also be done for capacity development through civil society conferences and workshops where activists engaged with questions of global governance can productively exchange experiences across issues, institutions and campaigns. However, these costly gatherings are per force rare and involve only limited numbers of advocates. Complementary efforts might therefore be dedicated to developing a permanent resource centre for civil society initiatives on global governance. Such an institute could provide activists with services such as: assembling records of previous campaigns on global governance questions; mapping networks of regulation and power in relation to different global issues; translating important civil society and global governance documents into relevant languages; and acting as an incubator for new ideas and programmes on collective citizen engagement of global governance agencies.

\section{More coordinated relations}

As well as enhancing campaigner competence, a global civil society resource centre could also help to address a more general need for improved coordination in civil society activities vis-à-vis global governance. Many past citizen initiatives on issues of global regulation have seen their limited resources dissipated through fragmentation, duplication of efforts, and internecine competition. Moreover, many global policymakers have been reluctant to engage with what seems in their eyes to be a diffuse swarm of often ill-defined and poorly accountable civil society activities. These officials have therefore preferred to focus their relations with citizen associations on a restricted circle of well-known quantities, particularly major business lobbies and high-profile NGOs. Yet this 
narrow approach has reinforced the problems of delegitimating exclusion emphasised earlier.

Several initiatives have developed, especially over the past decade, to assemble civil society voices vis-à-vis global governance. For example, the Conference of Non-Governmental Organisations in Consultative Relationship with the United Nations (CONGO, dating from 1948) and Social Watch (launched in 1995) have provided venues for civil society associations to congregate in relation to the UN system. The Montreal International Forum (started in 1998), the Bridge Initiative (begun in 2001) and the World Forum of Civil Society Networks-UBUNTU (formed in 2001) have sought to facilitate civil society coordination in respect of a wider range of multilateral institutions. The World Economic Forum (1971), CIVICUS-Worldwide Alliance for Citizen Participation (1993), the State of the World Forum (1995), and the World Social Forum (2001) have also constructed broad tents for civil society, albeit without seeking specifically to engage global governance agencies.

Welcome though these efforts to foster more coordinated civil society engagement of global governance have been, they have generally suffered from some of the other shortcomings highlighted in the present analysis. Thus, for example, the initiatives have tended to limit their scope of 'global governance' to the most visible intergovernmental organisations, while overlooking transgovernmental networks and private global regulation as well as incipient interregionalism and translocalism. Moreover, with the exception of CONGO in relation to the UN, existing mechanisms to coordinate civil society activities on global governance have usually focused on the macro-level of major conferences and general policy frameworks, giving less attention to day-to-day processes of policy formulation and implementation. Furthermore, aside from the World Social Forum these initiatives have generally limited coverage of 'global civil society' to NGOs, and the more globally connected NGOs at that, thereby excluding large swathes of global citizen action in social movements and more locally based 
associations. In addition, apart from the World Economic Forum most of these projects have worked with small and fragile resource bases. Nor - anticipating the next discussion point below - have these mechanisms for civil society coordination incorporated systematic processes to secure their accountability, either towards the participating civil society groups or towards constituencies in wider society.

The challenge of nurturing more systematic civil society engagement of global governance therefore remains. On the one hand, efforts could be directed at improving existing coordination frameworks with wider coverage, greater inclusion, upgraded competence, higher resources, and greater accountability. On the other hand, new complementary venues could be developed with the specific purpose of coordinating civil society engagement of the full complex of global governance institutions (Scholte, 2007).

\section{More accountable engagement}

Finally among the five main prescriptions for future development put forward here, the potentials for civil society legitimation of global regulation can be furthered with increased accountability on the part of the citizen groups to their various constituencies. Constructive accountability dynamics can promote increased civil society relations with global governance agencies, since the authorities and the general public would then have more confidence in the bona fides of these citizen associations. At the same time, when pursued in a positive fashion, greater attention to accountability can prompt civil society groups to become more inclusive, competent and coordinated in their relations with transplanetary regimes.

Civil society activities largely advance the legitimacy of global governance by making those regimes more accountable. With accountability, holders of power (in this case transplanetary regulatory authorities) are made answerable for the 
ways that they use or fail to use that power, particularly when their actions and omissions result in harms. Civil society monitoring of the moral, legal, technical and democratic credentials of global governance has been one important way to promote the legitimacy of those regimes, particularly in the absence of strong formal oversight by parliaments and courts. In a watchdog function citizen groups endorse transplanetary regulatory agencies when these rulers perform well and call them to task when they fall short. In cases of failure, civil society circles may help to restore legitimacy to the global authorities by pressing for and obtaining restitution, for example, in the shape of apologies, policy changes, institutional reorganisations, staff reprimands, management resignations, reparations, and for particularly egregious abuses even incarcerations.

Yet civil society watchdogs of global governance must also be accountable themselves. After all, the actions and omissions of civil society groups vis-à-vis transplanetary regulation can also do damage, including by the frequent shortfalls of inclusion, competence and coordination described above. In particularly bad cases, civil society organisations in global politics lack a clear public constituency, rarely if ever consult their supposed beneficiaries, fail to report on their activities, escape rigorous financial controls, and offer aggrieved parties no channels for complaint and redress.

To correct such flaws in their own operations civil society associations require devices to ensure their own accountability - and through it their own legitimacy in exercising influence on global governance. The need for secure accountability on the part of actors in global civil society has been increasingly recognised of late, also by those actors themselves (Edwards, 2000; Chapman and Wameyo, 2001; Scholte, 2003: 87-94; Blagescu and Lloyd, 2006; Jordan and Van Tuijll, 2006; Ebrahim and Weisband, 2007: Part III). Less clear, however, is to whom these civil society groups should be accountable and by what means. 
To be sure, certain important measures are already in place to foster the accountability of civil society associations in their engagement of global governance processes. For example, formal civil society organisations are usually registered under relevant national statutes and thereby become accountable to state authorities. In such cases the executive or the judiciary can curtail or disband civil society bodies that break the law. In addition, certain global governance agencies operate accreditation schemes to vet civil society associations that seek a formal consultative status. Meanwhile those civil society groups that have memberships and/or a board of governors are accountable to these supporters and may lose their backing in response to poor performance. Many civil society initiatives are also accountable (via project reports and financial statements) to donors that fund their work, with the sanction of losing vital monies in cases of immoral, illegal, incompetent or undemocratic conduct. Organisational accountability further exists to staff inasmuch as employees may blow whistles on misconduct or resign. Critical assessments of a given civil society association published in the mass media, academic research and consultancy reports can promote its accountability to the general public. Moreover, civil society organisations working in the area of global governance have promoted mutual accountability within their sector through the development of self-regulatory codes of conduct and other quality assurance schemes. A notable recent initiative in this regard is the INGO Accountability Charter inaugurated in 2006 (INGO, 2007).

Yet arrangements to enhance the accountability of civil society activities in respect of global governance could be improved in three key respects. First, the credibility of the mechanisms just described depends in good part on the accountability in turn of the various monitors of civil society activities. Otherwise these controllers (be they governments, donors, mass media, academics or consultants) can abuse their power and use 'accountability' as a tool to suppress civil society. Every agent of accountability also needs in its turn to be sufficiently answerable for its actions on this subject. Thus constructive, effective and just 
oversight is better obtained when the various social actors are enmeshed in complex networks of multilateral mutual accountability. To this end substantial future efforts could be devoted to furthering not only the answerability of civil society bodies to officials, funders, journalists, researchers and consultants, but also vice versa.

A second major problem in existing accountability arrangements regarding civil society engagement of transplanetary governance is that they are heavily biased towards the powerful. Citizen group initiatives in global politics are mainly monitored by actors from elite quarters: donors, corporate media, academics, etc. In contrast, civil society work on global governance rarely includes systematic accountability to subordinated circles, even though it is often claimed that poor people and various minorities are major beneficiaries of civil society interventions in global regulation. Such asymmetric and undemocratic accountability reflects and reinforces the dynamics of marginalisation. When civil society associations are mainly made answerable to elites, accountability easily becomes part of hegemony rather than - as is often presumed - a way to resist it (Weisband and Ebrahim, 2007). Thus the future wants far more attention to ways that subordinated circles can obtain accountability from the powerful in civil society work on global governance issues.

A third significant improvement in measures to obtain accountability in civil society campaigns on global governance could be had with reorientation from negative and blunt policing to positive and imaginative learning. Current oversight of global civil society is heavily geared toward bureaucratic surveillance and punishment in relation to externally imposed targets. Although controls against malfeasance are doubtless necessary, accountability exercises can and should also be a supportive process for reflective learning, with positive and creative initiatives to rethink visions, goals and the ways that they are pursued. Without such learning civil society organisations fail to correct their shortcomings and underachieve. Thus on the whole future practices of accountability in civil society 
work concerning global governance need relatively less technocratic surveillance and relatively more organisational learning.

\section{Conclusion}

As the foregoing third part of this analysis has indicated, many challenges confront the enlargement and improvement of civil society engagement of global governance. To acquire greater consequence in the legitimation of global governance these relationships need substantial advances in terms of expanded proportions, enhanced inclusiveness, upgraded competence, raised coordination and improved accountability. Achieving these ends will take major efforts patiently sustained on multiple fronts over multiple years.

These efforts will be worthwhile for the ample fruits that they can bear. As seen in the second part of this paper, civil society activities can do much to advance the legitimacy of global governance. Civil society interventions are not the only way to raise moral standards, legal bases, material delivery, democracy and charismatic leadership in transplanetary regulation. However, civil society offers some of the most substantial and immediately available possibilities in this regard.

To neglect these potentials would be to lose one of the best opportunities to address one of the most pressing needs in contemporary politics, namely, to raise the legitimacy of global governance and thereby to facilitate its growth. The more global world of the twenty-first century needs major elements of effective and just global governance. A large scale of inclusive, competent, systematic, accountable global civil society activity is a vital vehicle to that destination. 


\section{References}

Ahrne, G. (1998) 'Civil Society and Uncivil Organizations', in J.C. Alexander (ed.), Real Civil Societies: Dilemmas of Institutionalization. London: Sage.

Batliwala, S. and L.D. Brown (eds) (2006) Transnational Civil Society: An Introduction. Bloomfield, CT: Kumarian Press.

Bello, W. (2002) De-Globalization: Ideas for a New World Economy. London: Zed.

Blagescu, M. and R. Lloyd (2006) 2006 Global Accountability Report: Holding Power to Account. London: One World Trust.

Brown, L.D. et al. (2001) Practice-Research Engagement and Civil Society in a Globalizing World. Cambridge, MA: Hauser Centre for Nonprofit Organizations, Harvard University.

Buchanan, A. and R.O. Keohane (2006) 'The Legitimacy of Global Governance Institutions', Ethics and International Affairs, vol. 20, no. 4, pp. 405-38.

Bull, B. and D. McNeill (2007) Development Issues in Global Governance: Market Multilateralism and Private-Public Partnerships. London: Routledge.

Cardoso, F.H. et al. (2004) We The Peoples: Civil Society, the United Nations and Global Governance. Report of the Panel of Eminent Persons on United Nations-Civil Society Relations. New York: United Nations General Assembly Document A/58/817.

Chapman, J. and A. Wameyo (2001) Monitoring and Evaluating Advocacy: A Scoping Study. London: ActionAid.

Clark, J.D. (ed.) (2003) Globalizing Civic Engagement: Civil Society and Transnational Action. London: Earthscan.

Cohen, J.L. and A. Arato (1992) Civil Society and Political Theory. Cambridge, MA: MIT Press.

CSGR (2007) Centre for the Study of Globalisation and Regionalisation, Globalisation Index, at www.csgr.org, accessed on 9 January.

Cutler, A.C. et al. (eds) (1999) Private Authority in International Affairs. Albany, NY: State University of New York Press.

Della Porta, D. et al. (2006) Globalization from Below: Transnational Activists and Protest Networks. Minneapolis: University of Minnesota Press.

Ebrahim, A. and E. Weisband (eds) (2007) Global Accountabilities. Cambridge: Cambridge University Press.

Edwards, M. (2000) NGO Rights and Responsibilities: A New Deal for Global Governance. London: Foreign Policy Centre.

Edwards, M. (2004) Civil Society. Cambridge: Polity.

Edwards, M. and J. Gaventa (eds) (2001) Global Citizen Action. Boulder, CO: Rienner.

Eschle, C. and B. Maiguascha (eds) (2005) Critical Theories, International Relations and 'The Anti-Globalisation Movement': The Politics of Global Resistance. London: Routledge.

FIM (2007) Website of the Montreal International Forum, www.fimcivilsociety.org, accessed on 17 March. 
Florini, A.M. (ed.) (2000) The Third Force: The Rise of Transnational Civil Society. Tokyo/Washington, DC: Japan Center for International Exchange and Carnegie Endowment for International Peace.

Fox, J.A. and L.D. Brown (eds) (1998) The Struggle for Accountability: The World Bank, NGOs, and Grassroots Movements. Cambridge, MA: MIT Press.

Friedrichs, J. (2001) 'The Meaning of New Medievalism', European Journal of International Relations, vol. 7, no. 4 (December), pp. 475-502.

GCS (2001-) Global Civil Society Yearbook. Oxford: Oxford University Press (annual).

Gill, S. (2003) Power and Resistance in the New World Order. Basingstoke: Palgrave Macmillan.

Gilson, J. (2002) Asia Meets Europe. Cheltenham: Elgar.

GPF (2007) 'Arria and Other Special Meetings between NGOs and Security Council Members', website of the Global Policy Forum, www.globalpolicy.org/security/mtgsetc/brieindx.htm, accessed on 24 February.

Grande, E. and L. Pauly (eds) (2004) Reconstituting Political Authority: Complex Sovereignty and the Foundations of Global Governance. Toronto: University of Toronto Press.

Hall, R.B. and T.J. Biersteker (eds) (2003) The Emergence of Private Authority in Global Governance. Cambridge: Cambridge University Press.

Hänggi, $\mathrm{H}$. et al., Interregionalism and International Relations (London: Routledge, 2005).

Hardt, M. and A. Negri (2000) Empire. Cambridge, MA: Harvard University Press.

Hardt, M. and A. Negri (2004) Multitude: War and Democracy in the Age of Empire. New York: Penguin.

Held, D. et al. (1999) Global Transformations: Politics, Economics and Culture. Cambridge: Polity.

IMF (2003) 'Guide for Staff Relations with Civil Society Organizations', at www.imf.org/external/np/cso/eng/2003/101003.htm.

INGO (2007) website of the INGO Accountability Charter, www.ingoaccountabilitycharter.orgl, accessed on 23 February.

Jordan, L. and P. van Tuijll (eds) (2006) NGO Accountability: Politics, Principles, and Innovations. London: Earthscan.

Kaldor, M. (2003) Global Civil Society: An Answer to War. Cambridge: Polity.

Keane, J. (2003) Global Civil Society? Cambridge: Cambridge University Press.

Keck, M.E. and K. Sikkink (1998) Activists beyond Borders: Advocacy Networks in International Politics. Ithaca, NY: Cornell University Press.

Kingsbury, B.W. and N. Krisch (eds) (2006) 'Symposium on Global Governance and Global Administrative Law in the International Legal Order', European Journal of International Law, vol. 17, pp. 1-278.

Klein, N. (2000) No Logo. London: Flamingo.

Martens, K. (2005) NGOs and the United Nations: Institutionalization, Professionalization and Adaptation. Basingstoke: Palgrave Macmillan.

Munck, R. (2006) Globalisation and Contestation: The New Great CounterMovement. London: Routledge. 
NSI (2007) Website of the North-South Institute, www.nsi-ins.ca, accessed on 17 March.

O'Brien, R.J. et al. (2000) Contesting Global Governance: Multilateral Economic Institutions and Global Social Movements. Cambridge: Cambridge University Press.

Raustiala, K. (2002) 'The Architecture of International Cooperation: Transgovernmental Networks and the Future of International Law', Virginia Journal of International Law, vol. 43, no. 1 (Fall), pp. 1-92

Reinicke, W.H. (1999-2000) 'The Other World Wide Web: Global Public Policy Networks', Foreign Policy, no. 117 (Winter), pp. 44-57.

Robertson, R. (1992) Globalization: Social Theory and Global Culture. London: Sage.

Ronit, K. and V. Schneider (eds) (2000) Private Organizations in Global Politics. London: Routledge.

Rosenau, J.N. (2003) Distant Proximities: Dynamics beyond Globalization. Princeton, NJ: Princeton University Press.

Scholte, J.A. (2000a) 'Global Civil Society', in N. Woods (ed.), The Political Economy of Globalization. London: Macmillan, pp. 173-201.

Scholte, J.A. (2000b) Globalization: A Critical Introduction. Basingstoke: Palgrave, first edn.

Scholte, J.A. (2002) Civil Society Voices and the International Monetary Fund. Ottawa: North-South Institute.

Scholte, J.A. (2003) Democratizing the Global Economy: The Role of Civil Society. Coventry: Centre for the Study of Globalisation and Regionalisation, available at www.csgr.org.

Scholte, J.A (2004) 'The WTO and Civil Society', in B. Hocking and S. McGuire (eds), Trade Politics. London: Routledge, second edn, pp. 146-61.

Scholte, J.A. (2005) Globalization: A Critical Introduction. Basingstoke: Palgrave Macmillan, second edn.

Scholte, J.A. (2006) 'Political Parties and the Democratisation of Globalisation', in P. Burnell (ed.), Globalising Democracy: Party Politics in Emerging Democracies. London: Routledge, pp. 46-68.

Scholte, J.A. (2007) 'Looking to the Future: A Global Civil Society Forum?' in J.W. Walker and A.S. Thompson (eds), The Emergence of Global Civil Society. Waterloo: Wilfred Laurier University Press.

Scholte, J.A. (forthcoming) Civil Society and Global Democracy. Cambridge: Polity.

Scholte, J.A. with A. Schnabel (eds) (2002) Civil Society and Global Finance. London: Routledge.

Slaughter, A.-M. (2004) A New World Order. Princeton: Princeton University Press.

Stiglitz, J. (2002) Globalization and Its Discontents. New York: Norton.

Weisband, E. and A. Ebrahim (2007) 'Forging Global Accountabilities', in Ebrahim and Weisband (eds), Global Accountabilities. Cambridge: Cambridge University Press, pp. 1-38. 
Willetts, P. (ed.) (1996) 'Conscience of the World': The Influence of NonGovernmental Organizations on the UN System. Washington, DC: Brookings Institution.

Wiseman, G. (1999) '"Polylateralism" and New Modes of Global Dialogue', Leicester Diplomatic Studies Programme, Discussion Paper No. 59.

Zürn, M. (2005) 'Global Governance and Legitimacy Problems', in D. Held and M. Koenig-Archibugi (eds), Global Governance and Public Accountability. Oxford: Blackwell, pp. 136-63. 


\section{$\underline{\text { CSGR Working Paper Series }}$}

199/06 March

200/06 April

201/06 April

202/06 April

203/06 April

204/06 April

205/06 April

206/06 May

207/06 May

208/06 May

209/06 June

210/06 September

211/06 October

212/06 October

213/06 October
Eddy Lee and Marco Vivarelli

The Social Impact of Globalisation in the Developing Countries.

Jan Aart Scholte

Political Parties and Global Democracy

Peter Newell

Civil society participation in trade policy-making in Latin America: The Case of the Environmental Movement

Marcus Miller and Dania Thomas

Sovereign Debt Restructuring: The Judge, the Vultures and Creditor Rights

Fondo Sikod

Globalisation and Rural Development in Africa: The Case of the Chad-

Cameroon Oil Pipeline.

Gilles Quentel

The Translation of a Crucial Political Speech: G.W.Bush' State of the Union Address 2003 in Le Monde

Paola Robotti

Arbitrage and Short Selling: A Political Economy Approach

T.Huw Edwards

Measuring Global and Regional Trade Integration in terms of Concentration of Access

Dilip K. Das

Development, Developing Economies and the Doha Round of Multilateral Trade Negotiations

Alla Glinchikova

A New Challenge for Civic National Integration: A Perspective from Russia.

Celine Tan

Who’s ‘Free Riding'? A Critique of the World Bank’s Approach to Non-

Concessional Borrowing in Low-Income Countries

Richard Higgott

International Political Economy (IPE) and the Demand for Political Philosophy in an Era of Globalisation

Peter Waterman

Union Organisations, Social Movements and the Augean Stables of Global

Governance

Peter Waterman and Kyle Pope

The Bamako Appeal of Samir Amin: A Post-Modern Janus?

Marcus Miller, Javier García-Fronti and Lei Zhang

Supply Shocks and Currency Crises: The Policy Dilemma Reconsidered 
214/06 December

215/07 January

216/06 December

217/07 February

218/07 February

219/07 February

220/07 February

221/07 March

222/07 March

223/07 March
Gianluca Grimalda

Which Relation between Globalisation and Individual Propensity to

Co-Operate? Some Preliminary Results from an Experimental Investigation

Kui-Wai Li, Iris A.J. Pang and Michael C.M. Ng

Can Performance of Indigenous Factors Influence Growth and

Globalisation?

Marcus Miller and Lei Zhang

Fear and Market Failure: Global Imbalances and "Self-insurance"

Catherine Hoskyns

Linking Gender and International Trade Policy: Is Interaction Possible?

Dilip K. Das

South Asian Free Trade Agreement: Prospects of Shallow Regional Integration

Vanesa Weyrauch

Weaving Global Networks: Handbook for Policy Influence

Yuji Tamura

Preferences for Immigration Restriction and Opinions about Immigrant's

Economic Impacts

Dania Thomas and Javier García-Fronti

Good Faith in Sovereign Debt Restructuring: The Evolution of an Open Norm in

'Localised' Contexts?

Michela Redoano

Fiscal Interactions Among European Countries: Does the EU Matter?

Jan Aart Scholte

Civil Society and the Legitimation of Global Governance

\section{Centre for the Study of Globalisation and Regionalisation \\ University of Warwick \\ Coventry CV4 7AL, UK}

Tel: +44 (0)24 76572533

Fax: +44 (0)24 76572548

Email: csgr@warwick.ac.uk

Web address: http://www.csgr.org 